\title{
Comparing risk for different dairy farm management systems in Taranaki using the Dexcel Whole Farm Model
}

\author{
P.C. BEUKES, C.C. PALLISER, W.E. PREWER, G. LEVY, C. FOLKERS, \\ M.NEAL, M.E. WASTNEY and B.S. THORROLD \\ Dexcel, PB 3221, Hamilton \\ pierre.beukes@dexcel.co.nz
}

\begin{abstract}
The approach was to use the Whole Farm Model (WFM) and Taranaki climate to compare a conventional, twice-a-day milking farm system with variations of once-a-day (OAD) milking and high-input systems. The aim was to compare production, return on assets (ROA) and risk as affected by climate and price variability. Simulations were run over 9 different climate years (1995/1996 - 2003/2004). The high-input system had the highest production (1333 kg milksolids (MS)/ ha) and highest ROA (10.8\%), with variability thereof dampened by a feed buffer of higher quantity and quality that existed because of higher pasture yields ( $15.8 \mathrm{t}$ dry matter (DM)/ha with $200 \mathrm{~kg}$ nitrogen $(\mathrm{N}) / \mathrm{ha}$ vs. $13.5 \mathrm{t}$ $\mathrm{DM} / \mathrm{ha}$ with $105 \mathrm{~kg} \mathrm{~N} / \mathrm{ha}$ for the other two systems), maize silage and grazing-off. The high-input system was followed by the OAD and conventional systems in terms of production (1068 and $975 \mathrm{~kg} \mathrm{MS} / \mathrm{ha}$ respectively) and ROA ( $9.8 \%$ and $9.2 \%$ respectively). Both OAD and conventional systems showed risk values nominally lower than high-input, but both these systems were more severely affected by climatic variability, which lowered the average return and increased the risk relative to the return.
\end{abstract}

Keywords: climate variability, high input farming, once-a-day milking, return on assets

\section{Introduction}

Seasonal variability in pasture growth is one of the main challenges of pasture-based dairying in New Zealand. Seasonal factors like wet winters leading to pasture damage, delayed spring growth when feed demand is high, and summer/autumn droughts may result in variability in milk production and profitability (Verkerk 2002). An underlying goal for most pastoral livestock systems is to cope with environmental and systemgenerated variation (Beukes et al. 2002). Buffering against variation (or risk aversion) may be achieved by conservative stocking policies and tactical use of conserved feeds (Romera et al. 2004). Often the evaluation of farm systems with different stocking rates and supplementary feeding strategies are based on the results of farmlet trials spanning over 2-3 years, and then comparisons are made on the basis of production and economic farm surplus (EFS) data only (e.g.
Macdonald et al. 2001). Comparing different management strategies with the aim of achieving system robustness (high return with low risk) require a more objective evaluation of financial returns, which include risk evaluation by including climate variability over longer terms and payout and supplement price variability.

The Dexcel WFM was developed for simulating the complex and dynamic interactions between climate, management, and cow and pasture production. It lends itself as a useful tool to predict production and economics under different climatic conditions and with different farm management systems in place, and because it can simulate numerous permutations of climate, management and price variability at a fraction of the cost and time of farmlet trials, it can be used to objectively compare different management strategies. The model has been evaluated extensively against trial data (Palliser et al. 2001; Lile et al. 2002; Wastney et al. 2002) including OAD milking (Beukes et al. 2004).

Some of the limitations faced by Taranaki dairy farmers in the high altitude region are high pasture utilisation challenges for the early spring, and for the lower lying areas the summer dry spells. Better performing farmers of both regions appear to achieve gains by increasing pasture utilisation via higher stocking rate, while maintaining the same per cow production level and production spread. Increasing the length of the milking season does not appear to be part of the strategy of either group of top performing farmers (Wells et al. 1998).

The objective of this study was to use the WFM for the Taranaki region to explore the effect of climate and price variability on production, profit and risk for three typical farm systems: (a) a conventional farm with twice-a-day milking and $3.3 \mathrm{Jerseys} / \mathrm{ha}$, (b) a farm with OAD milking after Christmas, 3.5 Jerseys/ha and more days in milk, and (c) a high-input farm with more $\mathrm{N}$ fertilizer, maize silage, grazing-off and 4.2 Jerseys/ha.

\section{Methods}

\section{Basic model set-up}

The WFM version 8.9.6 was used for this exercise. Pasture growth in the WFM was driven by weather data (daily rainfall, radiation and temperature, supplied by NIWA) from New Plymouth over 9 seasons (1995/ 
Table 1 Three Taranaki farm systems modelled over 9 seasons (1995/1996 - 2003/2004).

\begin{tabular}{lccc}
\hline & Conventional & High-Input & OAD \\
\hline Number of cows & 49 & 63 & 53 \\
Breed & Jersey & Jersey & Jersey \\
Stocking rate (cows/ha) & 3.3 & 4.2 & 3.5 \\
Initial average live weight (kg) & 395 & 395 & 395 \\
Milking frequency & Twice-a-day & Twice-a-day & Twice-a-day till \\
& & & Christmas, thereafter \\
& & & OAD \\
Grazing-off & None & $66 \%$ of the herd for & None \\
Calving dates & & eight weeks & 6 Aug - \\
Drying-off dates & Aug Oct \\
Initial farm cover (kg DM/ha) & 29 Apr & 30 Jul - Oct & 30 May \\
$N$ fertilizer (kg/ha) & 2300 & 10 May & 2300 \\
Initial grass silage stack (t DM/cow) & 105 & 2300 & 105 \\
Other supplement stacks (t DM/cow) & 0.31 & 200 & 0.33 \\
\hline
\end{tabular}

Table 2 Default capital cost structure used in the model.

\begin{tabular}{lc}
\hline Item & Cost \\
\hline Value of live cow & $\$ 700$ \\
Land cost/ha & $\$ 18000$ \\
Share cost/kg MS & $\$ 5.40$ \\
Cost per dairy & $\$ 300000$ \\
Cost for all machinery & $\$ 80000$ \\
Land appreciation rate & $4 \%$ \\
Shares appreciation rate & $10 \%$ \\
Dairy appreciation rate & $-6 \%$ \\
Machinery appreciation rate & $-18 \%$ \\
Cow appreciation rate & $2 \%$ \\
\hline
\end{tabular}

1996 - 2003/2004), using the pasture growth model of McCall \& Bishop-Hurley (2003). "Molly" (Baldwin 1995) (version 4.13) was the cow model used. "Molly" was validated to represent a Jersey cow using trial data from a Taranaki OAD milking trial (Tong et al. 2002). The cow model included a function for photoperiod to represent lactation following calving in any season under NZ pastoral conditions (Beukes et al. 2005).

A modelled farm of 15 ha with 40 paddocks was set up for a typical Taranaki farm. Information describing this typical Taranaki farm was obtained from Dexcel consulting officers (Hughes \& Canton pers. comm. 2005), and included average farm cover at the beginning of the season (1 June), average initial cow live weight, amount of $\mathrm{N}$ fertilizer used, calving dates, residuals, conservation period, expected balance date, rotation lengths, planned start of mating and drying-off dates.

\section{Taranaki management systems}

The basic farm set-up was adjusted to represent three different low/medium altitude Taranaki farm systems (Table 1). Animal input files were compiled with similar age structures for the three farm systems. Individual cows were initialized in the model depending on age (2, $3,4+$ yrs), live weight and body condition score. Post- partum anoestrus was assumed to be 65 days with cycling every 21 days thereafter. All cows were mated (and assumed to conceive) between 28 October and 30 January when they were cycling.

\section{Economic input data}

The WFM simulates a scenario for a year and then uses the production data together with user-defined economic inputs to produce an economic report with a calculated EFS $(\$ /$ ha) and ROA ((EFS + Capital Gain) $/$ Assets = ROA \%). The EFS calculation is adjusted for the differences between farm cover, supplement stacks and cow condition at the end of the simulation compared to the start values.

Input values for Taranaki were derived from economic farm survey data (Dexcel 2005). For the OAD system the net stock income/cow was increased from $\$ 102$ (default) to $\$ 110$ to account for the selling of heavier cows and selling them later in the season (Newman pers. comm.). Wages cost/cow decreased from $\$ 62$ to $\$ 57.45$ for OAD to account for the freed labour time and the benefits accrued from that in terms of pasture improvement and savings on weekend relief milking (Newman pers. comm. 2005). Further changes to the OAD economic input were animal health costs down from $\$ 57 /$ cow to $\$ 55 /$ cow, and electricity costs down from $\$ 20 /$ cow to $\$ 17.18 /$ cow (Canton pers. comm.). Changes to the economic input for the High-Input system were repair and maintenance costs/ha up from \$241 (default) to $\$ 275$, vehicle costs/ha up from $\$ 146$ to $\$ 192$, and machinery depreciation rate up from $18 \%$ to $25 \%$ (Newman pers. comm.). Grass and maize silage used was priced at $\$ 200 / \mathrm{t} \mathrm{DM}$. This ignored the likely effect of weather on supplementary feed price, and could have resulted in an overestimate of returns for systems with high supplement use during poor seasons. Table 2 summarizes the default capital cost structure used in the model. The limitation of this analysis was that due to a 
paucity of data, possible differences in capital costs for different systems were not considered e.g. the costs of a feed pad for the High-Input system. This may have led to an overestimate of returns from this system.

\section{Risk report}

For the risk report, each system was simulated for each of the 9 seasons. The modelled production for each season together with a set of 100 random combinations of prices were used to calculate 100 possible ROAs for each system for each season. These prices were sampled using the Monte Carlo technique, assuming a normal distribution with price $/ \mathrm{kg}$ MS average of $\$ 3.90$, and standard deviation (SD) of $\$ 1$; supplement purchase cost/ DM average of $\$ 200$, and SD of $\$ 50$; and land appreciation rate average of $4 \%$, SD of $5 \%$ (Neal et al. 2004). From the $900 \mathrm{ROAs} / \mathrm{system}$ the average and SD (risk) were calculated. Assuming that the farmer always has the opportunity of investing in a risk free rate of $5 \%$ (e.g. government bonds), the farmer can then compare the excess return of a farm system (Average ROA 5\% risk free) to the risk, measured with the SD of the ROA. This allows farms to be compared with a Sharpe ratio (as per equation 1), with a higher Sharpe ratio representing a better farm (Hardaker et al. 2004).

Sharpe ratio $=($ Average $\mathrm{ROA}$ of farm system - Risk free rate)/SD of ROA

Equation 1

\section{Results}

The WFM predicted consistently higher MS yield for the High-Input farm over the 9 seasons. Predictions for the OAD system showed the highest comparative stocking rate and supplements fed of the three systems (Table 3).

The High-Input system showed the highest ROA, but also the highest risk (SD). Nevertheless, the excess return/unit risk (Sharpe ratio) for the High-Input system was the most favorable of the three systems (Table 4).

\section{Discussion}

The High-Input system had the highest average ROA over the 9 seasons, but with the greatest variability thereof. In the risk analysis, the effect of variability in payout on a system with higher MS yield resulted in a higher risk measurement for the High-Input system. However, this increase in risk was dampened because the High-Input system was better buffered against poor seasons. This buffering can be seen in the fact that the EFS for the High-Input system decreased by $41 \%$ from $\$ 2286 /$ ha for the best season $(2001 / 2002)$ to $\$ 1344 /$ ha for the worst season $(2002 / 2003)$. For the OAD system this decrease was $50 \%$ from $\$ 1890 /$ ha to $\$ 939 /$ ha, and for the Conventional system the decrease was 53\% from $\$ 1679$ / ha to $\$ 794 /$ ha. The High-Input system had a more favourable Sharpe ratio because of better returns and a relatively small increase in risk compared to the other two systems.

The higher returns in the High-Input system resulted from higher production/cow, and consequently a greater efficiency of production ( $\mathrm{kg} \mathrm{MS} / \mathrm{t} \mathrm{DM}$ ). This production was based on cheap and reliable feed from higher $\mathrm{N}$ input, and therefore pasture production, grazing-off and maize silage. The buffering not only meant there was a smaller likelihood of the High-Input system running out

Table 3 Predicted averages ( \pm SD) of KPI's for three Taranaki farm systems over nine seasons (1995/1996 2003/2004). Values with similar superscripts do not differ significantly at $P<0.05$.

\begin{tabular}{lccc}
\hline KPIs & Conventional & High-Input & OAD \\
\hline MS (kg/ha) & $975^{\mathrm{a}} \pm 14$ & $1333^{\mathrm{b}} \pm 13$ & $1068^{\mathrm{c}} \pm 15$ \\
MS (kg/cow) & $299^{\mathrm{a}} \pm 4$ & $317^{\mathrm{b}} \pm 3$ & $302^{\mathrm{c}} \pm 4$ \\
MS (kg/kg LWT) & $0.72^{\mathrm{a}} \pm 0.01$ & $0.75^{\mathrm{b}} \pm 0.01$ & $0.73^{\mathrm{c}} \pm 0.01$ \\
MS (kg/t DM feed eaten) & $73^{\mathrm{a}} \pm 0.9$ & $75.5^{\mathrm{b}} \pm 0.7$ & $74.3^{\mathrm{c}} \pm 0.9^{-0}$ \\
Days in milk/cow & $25^{\mathrm{a}} \pm 0$ & $268 \pm 0$ & $282 \pm 0$ \\
MS for season (kg/cow/day) & $1.2^{\mathrm{a}} \pm 0.02$ & $1.18^{\mathrm{b}} \pm 0.01$ & $1.07^{\mathrm{c}} \pm 0.02$ \\
Comparative stocking rate (kg LWT/t DM) & $98^{\mathrm{a}} \pm 12$ & $84^{\mathrm{b}} \pm 7.5$ & $105^{\mathrm{c}} \pm 12.8$ \\
Total pasture grown (t DM/ha) & $13.5^{\mathrm{a}} \pm 1.6$ & $15.8^{\mathrm{b}} \pm 1.8$ & $13.5^{\mathrm{a}} \pm 1.6$ \\
Supplements fed (kg DM/cow) & $371^{\mathrm{a}} \pm 245$ & $243^{\mathrm{b}} \pm 216$ & $478^{\mathrm{c}} \pm 255$ \\
Supplements fed (t DM/ha) & $1.21^{\mathrm{a}} \pm 0.8$ & $1.02^{\mathrm{b}} \pm 0.91$ & $1.69^{\mathrm{c}} \pm 0.9$ \\
Grazing-off (t DM/cow) & $0 \pm 0$ & $0.3 \pm 0$ & $0 \pm 0$ \\
Pasture eaten (t DM/ha) & $11.7^{\mathrm{a}} \pm 1.0$ & $14.3^{\mathrm{b}} \pm 1.2$ & $12.0^{\mathrm{a}} \pm 1.1$ \\
\hline
\end{tabular}

Table 4 Risk report for three Taranaki farm systems over nine seasons (1995/1996 - 2003/2004).

\begin{tabular}{lccc}
\hline & Conventional & High-Input & OAD \\
\hline Average ROA (\%) & 9.2 & 10.8 & 9.8 \\
SD of ROA (\%) & 4.96 & 5.49 & 5.11 \\
Sharpe ratio & 0.847 & 1.061 & 0.939 \\
\hline
\end{tabular}


of feed in poor seasons, but the average quality of the feed was also better in poor seasons in the High-Input system. This was demonstrated in the poor season of 2002/2003 (11t DM/ha pasture production) when large quantities of supplements had to be fed to the cows in all three systems, especially over the late summer/autumn period. However, during this time covers were over $2500 \mathrm{~kg} \mathrm{DM} /$ ha in the High-Input system compared to $2300 \mathrm{~kg} \mathrm{DM} / \mathrm{ha}$ and lower in the Conventional system. This meant that cows in the High-Input system only required $6 \mathrm{~kg} \mathrm{DM} / \mathrm{cow} /$ day of supplements compared to the $8 \mathrm{~kg} \mathrm{DM} / \mathrm{cow} /$ day in the Conventional system. At this stage supplements fed in the High-Input system consisted of a combination of grass- and maize-silage (approximately 10 and $10.5 \mathrm{MJ} \mathrm{ME} / \mathrm{kg}$ DM respectively) whereas cows in the Conventional system were fed grasssilage only. The combination of more feed from pasture, smaller quantities of supplements fed per day and better quality supplements fed, allowed the High-Input cows to produce better than their counterparts in the Conventional system. The better production during poor seasons reduced the overall variability of profit in the High-Input system, which was not cancelled by a concomitant increase in risk associated with the cost of this production.

The OAD system showed a better Sharpe ratio compared to the Conventional system. The high comparative stocking rate of the OAD system explains the high demand for supplement feeding, which will increase risk, but the higher production and lower cost of production (average $\$ 1.82 / \mathrm{kg}$ MS compared to $\$ 1.94 / \mathrm{kg}$ MS for Conventional) resulted in higher returns compensating for the higher risk. The better pasture utilisation and feed conversion of the OAD system compared to the Conventional system corroborates the trend for higher excess returns per unit risk when these key performance indicators (KPIs) improve.

Farmers who aim to achieve high excess return per unit of risk over the longer term should focus on maximizing pasture growth (within acceptable limits for $\mathrm{kg} \mathrm{N} / \mathrm{ha}$ ), increase pasture utilisation, aim for longer lactations (Beukes et al. 2004), be prepared to pay for off-farm grazing to get pasture covers up in the early part of the season, and buy-in quality supplements when they run out of pasture. Often late summer/autumn appears to be a critical time and feeding quality silage, like whole-crop cereal silage, could result in increased production compared to when grass silage is fed (Stevens et al. 2004).

The next logical step would be to implement the optimisation procedure of the WFM (Neal et al. 2004; Neal et al. 2005) to explore the combination of management decisions for each of the different farm systems that would provide the farmer with the highest excess returns per unit of risk.

\section{Conclusions}

This exercise showed the potential of the WFM to predict ROA and Sharpe Ratio as evaluation criteria for farm systems, because it incorporates variability driven by season and economics. With a variable MS price, systems with higher production show greater variability in ROA. But if high production is achieved at low cost, the higher average ROA compensates for the increase in risk.

\section{ACKNOWLEDGEMENTS}

This study was funded by Dairy InSight (project 10079).

\section{REFERENCES}

Baldwin, R.L. 1995. Modeling ruminant digestion and metabolism. Chapman \& Hall, London, UK.

Beukes, P.C.; Cowling, R.M.; Hig gins, S.I. 2002. An ecological economic simulation model of a nonselective grazing system in the Nama Karoo, South Africa. Ecological Economics 42: 221-242.

Beukes, P.C.; Thor rold, B.S.; Wastney, M.E.; Palliser, C.C.; Clark, D.A. 2004. Modelling farm systems with once-a-day milking. Proceedings of the New Zealand Society of Animal Production 64: 237-240.

Beukes, P.C.; Thor rold, B.S.; Wastney, M.E.; Palliser, C.C.; Macdonald, K.A.; Bright, K.P.; Lancaster, J.A.S.; Palmer, C.A.J.; Auldist, M.J. 2005. Modelling the bi-peak lactation curves of summer calvers in New Zealand dairy farm systems. Australian Journal of Experimental Agriculture 45: 1-7.

Dexcel Ltd. 2005. Economic survey of New Zealand dairy farmers, 2003-2004. Hamilton.

Hardaker, J.B.; Huirne, R.B.M.; Anderson J. 2004. Coping with risk in agriculture (2nd edition). $\mathrm{CAB}$ International, Wallingford, UK.

Lile, J.A.; Bright, K.P.; Palliser, C.C.; Prewer, W.E.; Wastney, M.E. 2002. Modelling dairy production in different regions of New Zealand. Proceedings of the New Zealand Society of Animal Production 62: 7-11. Macdonald, K.A.; Penno, J.W.; Nicholas, P.K.; Lile, J.A.; Coulter, M.; Lancaster, J.A.S. 2001. Farm systems - Impact of stocking rate on dairy farm efficiency. Proceedings of the New Zealand Grassland Association 63: 223-227.

McCall, D.G.; Bishop-Hurley, G.J. 2003. A pasture growth model for use in a whole-farm dairy production model. Agricultural Systems 76: 1183-1205.

Neal, M. 2004. Optimising return in a whole-farm model under conditions of risk. Proceedings of the Annual Australian Agricultural and Resource Economics Conference 48: 1-19. 
Neal, M.; Drynan, R.; Fulkerson, W.; Levy, G.; Wastney, M.; Post, E.; Thorrold, B.; Palliser, C.; Beukes, P.; Folkers, C. 2005. Optimisation of a whole-farm model. Proceedings of the Annual Australian Agricultural and Resource Economics Conference 49: 1-29.

Palliser, C.C.; Wastney, M.E.; Bright, K.P.; Macdonald, K.A.; Penno, J.W. 2001. Modelling the lactation curves of New Zealand cows. Proceedings of the International Congress on Modelling and Simulation 4: 1853-1858.

Romera, A.J.; Morris, S.T.; Hodgson, J.; Stirling, W.D.; Woodward, S.J.R. 2004. A model for simulating rulebased management of cow-calf systems. Computers and Electronics in Agriculture 42:67-86.

Stevens, D.R.; Platfoot, G.J.; Hyslop, M.G.; Knight, T.L.; Corson, I.D.; Littlejohn, R.J. 2004. Dairy cow production when supplemented with whole-crop cereal silages in spring and autumn. Proceedings of the New Zealand Grassland Association 66: 75-82.

Tong, M.J.; Clark, D.A.; Cooper, C.V. 2002. Once-aday milking: Possible and profitable? Proceedings of the Ruakura Farmers 'Conference 54: 53-54.

Verkerk, G. 2002. Pasture-based dairying: challenges and rewards for New Zealand producers. Theriogenology 8773: 1-9.

Wastney, M.E.; Palliser, C.C.; Lile, J.A.; Macdonald, K.A.; Penno, J.W.; Bright, K.P. 2002. A whole-farm model applied to a dairy system. Proceedings of the New Zealand Society of Animal Production 62: 120123.

Wells, J.; Bridges, M.; Malcolm, B.; Malcolm, J. 1998. Introduction to Taranaki. Dairyfarming Annual 50: 110. 